\title{
Preparing Transformative Future Workforce through Literary Novels in Management Classroom
}

\author{
Ms. Dhvani Pandya \\ Assistant Professor \\ St. Kabir Institute of Professional Studies
}

\begin{abstract}
:
With increasing competition in business world, the present recruitment process is more focused on finding an employee with a perfect combination of skills. People who can practically apply their theoretical knowledge are given an added advantage than others. Generation $\mathrm{Z}$ is also willing to incorporate their learning through practical experiences. Literature is a mirror to society thatis full of Real-life relatable examples. Using English Literature in the management classroom resembles a very prominent case study method for encouraging students' critical and analytical thinking ability.

This paper aims to reveal how the discussion of Literary Novels in management classrooms helps as a teaching tool. This tool provides students opportunities to uplift their critical thinking ability and sharpen their analytical approach towards business. It prepares management students to think beyond the theory and read between the lines. The paper examines the concept of the novel based case known as Novel Case Format published by Harvard Business School and used as a teaching tool in the management classroom and maps the concepts applied by the students.
\end{abstract}

Keywords: Novel Case Format, Innovations in Management Education, Critical Thinking, Transformative Future workforce.

\section{Introduction:}

"Education is a natural process that is carried out by the child and is not acquired by the words, but the experiences in the environment"

Dr. Maria Montessori

The study of every profession requires practical learning exposure which conditions professionals' minds for their future work life. A doctor is never allowed to treat a patient purely based on his professional degree, he/she requires to undergo a training period under some licensed practitioner. Similarly, Management professional needs to take serious business decisions where their critical and analytical thinking ability is tested. For example, to generate an annual turnover plan, businessmen need to make some decisions, analyse certain data and then measure the outcome based on certain strategies. Now, this is possible 
on a piece of paper, but when it comes to implementing those ideas, sometimes businessmen fail. That is why the modern management education system has increased their focus on including more case studies in their programme so that they can prepare students for future business challenges by giving them the exposure of real-world scenarios. Management courses nowadays are developed with the focus on creating a future employees who can generate better results for society. Case study method no doubt works best in management practices but now it's time to rethink and re-evaluate the case study method. The best teaching tool that resembles the case study method, is introducing literary novels to inculcate management principles.

Using illustration to annotate theory is a well-accepted management practice used in ancient times also. Aesop's fables and Panchatantra stories are the best paragon for teaching the importance of ethics. An Italian scholar Machiavelli used stories of ancient Greece to inculcate management practices. If we talk about Indian History, Mata Jijabai used the stories of famous personalities teaching leadership lessons to her son Shivaji Maharaj. Including English Literature in the syllabus of Management Programmes can maintain this standard practice and make students determine the principles of modern management interestingly. The Plot, Characters, Structure, Storyline, Dialogues, Reaction of the Protagonist on situations, Theme,etc of the literary novels can provide him/her many candid management lessons and Moreover it can enhance their employability by developing a desired 'Skill Set' by the corporates. As such, Literature can become that teaching tool that bridges the gap between theory and application. Many times the students put themselves into the shoes of the protagonist and try to come out from his cocoon, analyse the situation and provide solutions.

\section{Literature Review}

Richard L. Nolan (2013) in his working paper', 'Management: Theory and Practice, and Cases' discusses his own experience of discussing management cases at Harvard Business School, one of the leading B-schools. He, in the same paper, considers an MBA degree where a student must engage himself in the journey of mastering the ability to analyse the pertinent issues of the business world. Though case discussions become prominent in B-schools, He considers this exposure quite of less quality, repetitive and failed attempts by some faculty members. The classrooms have filled with more lectures about the case than quality discussions. Looking up to the demand of the Management Curricula, sometimes the single page "arm-chaired" written case to spice up the dry lectures end up with no academic fruitful learning experiences. Nolan does not reject the idea of having case discussions in class, what he is more focused on is, he quality of discussions.

The North American Case Research Association (2013) in the review of NACRA Case Precis declared that with the global demand for breakthrough innovations, the possibilities for expanding the form and method of case discussions have to be improved. One interesting method is Novel Case Format introduced by NACRA in association with HBS. Novel Case

\footnotetext{
${ }^{1}$ This working Paper are Richard Nolan's own experiences of introducing new teaching pedagogies at $\mathrm{HBS}$
} 
Format ${ }^{2}$ has successfully created the cases led by different business scenarios titled 'Adventure of an IT Leader' with the protagonist, Jim Barton who plays the role of a successful loan officer and who is given a new responsibility of being a CIO.

Nolan discusses the success of this first book continued in the next book 'Harder than I Thought' in which Jim Barton is portrayed as a 21st century CEO. The authors of these books organized the collection of these cases in the classic story format on Joseph Campbell's monomyth where a hero goes on an adventure and identifies a decisive crisis, fights with it and returns home transformed. When these cases were discussed in class, the faculty could engage students in relating Jim Barton's story and make them able to think how the protagonist sets his Hero's journey and learns to be an effective CIO.

Nolan comments that, "Discussions on these novel based cases make students 'walk in the shoes of the IT team', forced to 'walk in the shoes of the CEO' and enables them to switch their positions to the CEO's perspective." This is the psychology that once you make any decision, you become very defensive about your own decision and highly become critical of providing alternate analytical solutions. Walking into the shoes of the characters stimulates critical thinking abilities, Morover, it maintains an interest in students and encourages them to identify what is next?

The topics covered in the curriculum of Management degree changes from time to time and continuously evolving from its very nature. (Harrington \& Griffin, 1990). This is the reason why the treatment of dealing with some of the major ideas like Leadership, Ethics, Business Values, Motivation, and Business Crisis should be changed for the sustainability of future workforce who can resist their creativity at the time of crisis by providing viable solutions. This becomes a reason that the faculties should create pre-formulated situations to which students can give their opinions.

Soma Tandon (2014) in her doctorate thesis has evaluated the need to introduce literature in Management Classroom. She considers Literature an aid to develop business judgement. Using Fiction in the classroom generates the complexities of real-world demonstrated by different characters provides a critical platform to students with an added advantage of its entertainment value. Moreover, it inculcates Management Skills that prepare students for upcoming real-world challenges.

Danzig (1999) believes that reading fiction provides you opportunities that you can understand the world from different viewpoints, different psychologies. It enables Management students to peep into the life of different business areas and come out with solutions. According to McKinney and Yoos (1998), "Artificially isolated, functionally oriented, teacher-centered courses tend to reinforce isolated, functionally oriented, passive thinking in students" (p. 618).

\footnotetext{
${ }^{2}$ Novel Case Format is built on a foundation of field case development by crafting to extend the case method into a set of integrated cases which form a coherent story.
} 


\section{Literary Novels vs. Case Study Method}

The intention of using Case Studies in the classroom is to determine the principles of Organization Management through the real-world business problem. This technique is no doubt considered the best and in fact introduced in 1869 by Harvard Business School. It has been becoming very dominant since then. This may be the reason why the Management Students are hardly exposed to the non-business course syllabus.

Shetty in his research Paper 'Management Education in India: Trends, Relevance and Challenges ahead' clearly mentions that the present Indian Management Education needs a paradigm shift to produce Globally Competent future workforce. By Globally Competent he doesn't mean qualified professionals; he means the future business leaders who can transform himself and the team at the time of crisis. Diane Coutu (2006) argues that, 'Literature in its very nature is subjective and open-ended han the highly researched and contextualized case studies'. For example, William Shakespeare's 'Julius Caesar' teaches more lessons on leadership than any of the business books or journals. Anne Kreamer (2012) in the article 'The Business Case for Reading Novel' justifies that the neuronal pathways in the brain are activated while a person reads literature which ultimately helps a person to understand the human emotions better. In $\mathrm{fMRI}^{3}$ studies, the neuroscientists detected that the prefrontal cortex (part of the Brain) gets activated when people read fictions and this part of the brain helps people in goal setting.

Stanusch, Agata \& Wankel, Charles (2011) in their Handbook of Research on 'Teaching Ethics in Business and Management Education' discuss the advantages of using novels over case studies in classrooms. They have written that, using novels or short stories make students think over multidimensional angles discussed through each narratives, whereas case studies have insufficient details to reach the sound decision.

Michaelson, C. (2015) in his book review on 'Exploring Capitalist Fiction: Business through Literature and Film by Edward W. Younkins suggests that literary texts and films present various realistic issues with wider contexts of story. This is the reason why it compels readers more than textbooks or case studies. Youkins considers this form a replica of the business world which promotes active learning. From the educator's perspective also he considers literature strong. He argues that "The use of fiction, including novels, plays, and films, can enrich teaching materials in both educational and business settings. Fiction can be a powerful force to teach, educate, and move students and employees in ways that lectures, case studies, textbooks, articles, and anecdotes cannot."

\footnotetext{
${ }^{3} \mathrm{FMRI}$ (Functional magnetic resonance imaging or functional MRI) measures brain activity by detecting changes associated with blood flow.
} 


\section{Some Examples of Literature which can be used as Business Case.}

Diane Coutu in his article specifies some of the instances of using literature in business classrooms by Joseph Badaracco, Professor of Business Ethics. Prof. Badaracco believes that discussing literature in class provides students with a well-rounded image of leaders of all ages. Arthur Miller's play 'Death of a Salesman' simulates the question in students' minds about the fall of the protagonist Willy Loman because of his wrong dreams. This situation enables students to think over the noxious power dreams have in your life and how to overcome them.

The leaders or managers portrayed in literature fail, transform and succeed. The journey of their happiness becomes the journey of students when they discuss it in class. One such Indian play 'Tughlaq' who was considered a Mad king of Delhi sultanate becomes the energizer of students' minds when they discuss 'Tughlaq' by wearing Tughlag's shoe. The students analyse the reasons behind Tughlaq's failure. This makes students more confident about how to weave their path of success.

Badaracco, when interviewed by Coutu, was asked about his experiences of using Literature in the classroom. He shared his experience of discussing a short story by Joseph Conrad, 'The Secret Sharer', in the leadership training programme of business executives. He found that, usiness executives could easily connect and interpret literary text with esoteric business principles. The reason behind this is explained by him further that, 'The Secret Sharer' describes a protagonist, a new captain, who conceals a killer on his ship. This decision of his violates the law of the sea but he firmly believes that the man was falsely accused which raises a question of character and choice in front of him. Throughout the story, he learns to grapple with the hard times between the responsibilities and empathy. He was tired and almost reckless testing his limits until he climax of the story. Prof. Badaracco made the executives experience those limits and resonate with their managerial skills.

Malcolm Gladwell's book 'Blink: A power of Thinking without thinking' teaches the power of the human brain which is capable enough to take snap judgements. The topics like, consumer psychology, making snap judgement, 'priming' the customer's mind, affecting consumer psychology, less is more etc increase student's analytical ability. Interestingly, students start talking in the language of 'Blink' and realize the power of snap decisions.

\section{Findings \& Conclusion}

From the secondary research, it has been observed that now the time should change because Management students need the approaches where they can be better decision- makers, better leaders, or any other managerial positions.

It is also observed through this research that, though HBS has started using case methods in their curricula, their research team has implemented the Novel Case Format. So, the parent of the baby encourages innovation. One thing can be claimed from this research that literature 
can become a very powerful tool to augment the concepts, theory, and principles of management. This study will further motivate to extend the research on Management set up who uses literary texts and further map the outcome from students in terms of feedback. The focus of this study is not to disregard the case study method, but it just highlights that characters from literary texts can create an entertaining experience results into holistic skill enhancement of students.

\section{Works Cited}

1. Nolan, Richard L., Management: Theory and Practice, and Cases (September 11, 2013). Harvard Business School Research Paper Series \# 14-026, Available at SSRN: https://ssrn.com/abstract=2326452 or http://dx.doi.org/10.2139/ssrn.2326452

2. Harrington, K. V., \& Griffin, R. W. (1990). Ripley, Burke, Gorman, and Friends: Using the Film "Aliens" To Teach Leadership and Power. Organizational Behavior Teaching Review, 14(3), 79-86. https://doi.org/10.1177/105256298901400310

3. NACRA. (2013). NACRA CASE PRECIS. NOVEL CASE FORMAT . HBS.

4. Shetty- Management Education in India: Trends, Relevance and Challenges ahead'. From Informaticsjournals.com: (Volume 8, Issue 2, December 2014) http://www.informaticsjournals.com/index.php/nmr/article/view/18407

5. Anne Kreamer The business case of Reading Novels from HBR Managing Yourself (january 11, 2012 2012) https://hbr.org/2012/01/the-business-case-for-reading

6. Diane Coutu: Article titled 'Leadership in Literature' from HBR Managing PeopleMarch 2006 Issue https://hbr.org/2006/03/leadership-in-literature

7. Michaelson, C. (2015). Exploring Capitalist Fiction: Business through Literature and Film, by Edward W. Younkins. Lanham, MD: Lexington Books, 2014. 331 pp. ISBN: 978-0-7391-8426-4. Business Ethics Quarterly,Volume 25(Issue1), 151-154. doi:10.1017/beq.2014.5

8. Stanusch, Agata \& Wankel, Charles. (2011). Handbook of Research on Teaching Ethics in Business and Management Education. 10.4018/978-1-61350-510-6. 